Summer 2003

\title{
Prescriptive Jurisdiction over Internet Activity: The Need to Define and Establish the Boundaries of Cyberliberty
}

Samuel F. Miller

Indiana University School of Law

Follow this and additional works at: https://www.repository.law.indiana.edu/ijgls

Part of the Computer Law Commons, International Law Commons, and the Internet Law Commons

\section{Recommended Citation}

Miller, Samuel F. (2003) "Prescriptive Jurisdiction over Internet Activity: The Need to Define and Establish the Boundaries of Cyberliberty," Indiana Journal of Global Legal Studies: Vol. 10 : Iss. 2 , Article 8.

Available at: https://www.repository.law.indiana.edu/ijgls/vol10/iss2/8

This Note is brought to you for free and open access by the Law School Journals at Digital Repository @ Maurer Law. It has been accepted for inclusion in Indiana Journal of Global Legal Studies by an authorized editor of Digital Repository@Maurer Law. For more information, please contactrvaughan@indiana.edu.

\section{$\Psi$}

JEROME HALL LAW LIBRARY

INDIANA UNIVERSITY

Maurer School of Law
Blooming ton 


\title{
Prescriptive Jurisdiction over Internet Activity: The Need to Define and Establish the Boundaries of Cyberliberty
}

\author{
Samuel F. Miller*
}

\section{INTRODUCTION}

Globalization occurs at the nexus of politics, culture, technology, finance, national security, and ecology. "Globalization" refers to the increasingly "complex, dynamic legal and social processes" occurring throughout the world. ${ }^{2}$ It is the development of a global mindset that challenges the traditional political, social, and economic characteristics of nations and has led to the "deterritorialization and reterritorialization of [vast] policy spaces." Many of the changes and challenges attributed to globalization rely on the exchange of information throughout the world, making "the flow of ideas across national borders" a key agent of globalization. ${ }^{4}$ Due to the increasing availability of personal computers and software, the Internet provides the ideal forum for information transfer. ${ }^{5}$

The Internet engenders "the notion of distributed power: decentralization, openness, possibility of expansion, no hierarchy, no center, no conditions for authoritarian or monopoly control." The Internet has become vital to the

* B.A., 2000, Xavier University; J.D., 2003, Indiana University School of Law-Bloomington. I would like to thank my parents, Shirley and Russell Miller, for their support and Professor Hannah Buxbaum of the Indiana University School of Law-Bloomington for her advice and guidance in the preparation of this note.

1. See generally Thomas L. Friedman, The Lexus and the Olive Tree 21 (1999).

2. See Alfred C. Aman, Jr., Introduction, 1 Ind. J. Global Legal Stud. 1 (1993).

3. Aseem Prakash \& Jeffrey A. Hart, Coping With Globalization: An Introduction, in Coping With Globalization I, 3 (Aseem Prakash \& Jeffrey A. Hart eds., 2000).

4. Id. at 3 .

5. "Flows of money, goods and people are accelerated by the various technologies in use, particularly those from within the telecommunications sector." Barrif Axford, The Global System 109 (1995).

6. Saskia Sassen, Globalization and Its Discontents 177 (1998). 
broader dynamics of organizing global society, "both economically and politically."

One of the vital aspects of organizing global society has been individual liberty. With the introduction of the Internet, traditional notions of liberty are challenged. The global reach of information transfer requires examining liberty in its new form- "cyberliberty." Cyberliberty expands across all borders, affects all nations, and as of yet, has not been defined by any nation. This note recommends a definition of cyberliberty in order to provide a legal foundation for regulating conduct on the Internet. The definition is predicated upon freedom from the control and influence of states through their assertion of prescriptive jurisdiction, a liberty that has always been an essential element of sovereignty. ${ }^{8}$

Part I briefly describes how traditional international law principles of prescriptive jurisdiction have been applied to activities on the Internet. It then identifies some limits to these methods that arise from the unique characteristics of the Internet. Part II surveys philosophic conceptions of liberty, recognizing the implications of liberty on the Internet, and recommends a definition of cyberliberty that favors expansive liberty and clear expectations for Internet actors.

\section{Prescriptive Jurisdiction over Internet Activity}

Despite the unique quality of the Internet as a key agent of globalization, and some scholarly arguments that the Internet should not be regulated under traditional standards, ${ }^{9}$ jurisdiction over Internet-related activity is still generally tested under international jurisdictional law. ${ }^{10}$ Jurisdiction exists in three forms:

7. Id. at 191; Henry H. Perritt, Jr., argues that "the Internet and other forces of globalization are eroding traditional institutions of sovereignty." Henry H. Perritr, Jr., Law and the InforMation Superhighway $\$$ I 4.18 (2000). He points out that some criticism of the Internet as a positive force of globalization does exist and avoids the criticism of wearing "rose colored glasses" when discussing globalization and the Internet. Id.

8. See S.S. “Lotus" Case (Fr. v. Turk.), 1927 P.C.I.J. (ser. A) No. 10, at 18-19, available at http:// www.worldcourts.com/pcij/eng/cases/lotus.htm [hereinafter Lotus].

9. Lawrence Lessig, The Zones of Cyberspace, 48 Stan. L. Rev. 1403 (1996) (citing David R. Johnson \& David Post, Law and Borders-The Rise of Law in Cyberspace, 48 Stan. L. Rev. 1367, 1387-91 (1996)).

10. See generally Stephan Wilske \& Teresa Schiller, International Jurisdiction in Cyberspace: Which States May Regulate the Internet?, 50 Fed. Сомм. L.J. 117 (1997). 
jurisdiction to prescribe, to adjudicate, and to enforce." The primary jurisdictional problem that arises in relation to the Internet as a platform of globalization is one of prescriptive jurisdiction. It is the application of a single state's laws to Internet content that gives rise to complication. For example, may State A prohibit citizens of State B, located in State B, from posting advertisements for purple farm tractors on the Internet simply because State A prohibits the sale of purple farm tractors? Questions of this sort have strong implications for the global character of the Internet.

A firm basis for jurisdiction to prescribe is required to justify the infringement of sovereignty that would accompany regulation of Internet content. As stated in the Permanent Court of International Justice's opinion in the Lotus case, "a state ... may not exercise its power in any form in the territory of another state," and jurisdiction "cannot be exercised by a state outside its territory except by virtue of a permissive rule derived from international custom or from a convention." 12 As the Federal District Court for the Southern District of New York has noted,

The Internet is a worldwide phenomenon, accessible from every corner of the globe. [A defendant] cannot be prohibited from operating its Internet site merely because the site is accessible from within one country in which its product is banned. To hold otherwise would be tantamount to a declaration that this Court and every other court throughout the world, may assert jurisdiction over all information providers on the global World Wide Web. ${ }^{13}$

\section{A. Traditional Bases for Prescriptive Jurisdiction}

International law recognizes five sources of prescriptive jurisdiction: the nationality principle, the subjective territoriality principle, the objective territoriality

11. See Asaad Siddiqi, Welcome to the City of Bytes? An Assessment of the Traditional Methods Employed in the International Application of Jurisdiction over Internet Activities-Including a Critique of Suggested Approaches, 14 N.Y. INT'L L. Rev. 43, 61-64 (2001).

12. Lotus, supra note 8, at 18-19. The Lotus case elucidates many of the foundations for international jurisdiction that are now recognized as general principles of international law.

13. Playboy Enter., Inc. v. Chuckleberry Publ'g, Inc., 939 F. Supp. 1032, 1039 (S.D.N.Y. 1996) (quoting defendant's brief). But see Jane C. Ginsburg, Extraterritoriality and Multiterritoriality in Copyright Infringement, 37 VA. J. INT'L L. 587, 591-92 (1997). 
principle, the protective principle, and the universal jurisdiction principle. ${ }^{14}$ Only the nationality principle and the two territoriality principles can be, or have been, applied to the regulation of Internet information transfers. ${ }^{15}$

\section{The Nationality Principle}

The nationality principle has been described as supporting the jurisdiction of a nation to prescribe law "with respect to ... the activities, interests, status, or relations of its nationals outside as well as within its territory." 16 This principle is based on the assumption that a person grants the country of which he is a national the right to regulate his conduct, no matter where located. ${ }^{17}$ This principle is uncontroversial in international law. ${ }^{18}$

\section{The Subjective Territoriality Principle}

Often referred to as the subjective territoriality doctrine, the ability of sovereign states to exercise jurisdiction over property, persons, acts or occurrences within their own territory is a fundamental principle of international law. ${ }^{19}$ The Peace of Westphalia strengthened the notion of sovereignty of the nation state and specifically, the state right of territorial integrity. ${ }^{20}$ Jurisdiction within a

14. J.G. Starke, Introduction to International Law 202-35 (10th ed. 1989).

15. Under the protective principle, jurisdiction is invoked when a state proves that a threat to national security has occurred. See Kenneth C. Randall, Universal Jurisdiction Under International Law, 66 Tex. L. Rev. 785, 787-88 (1988). Universal jurisdiction grants jurisdiction over a limited number of offenses, such as terrorism, that are recognized as those of universal concern without regard to the location of the offense or nationalities of offender or offended. Id. at 788; see also María del Carmen Márquez Carrasco \& Joaquín Alcaide Fernández, In Re Pinochet, 93 Aм. J. INT'L. L. 960 (1999) (reviewing a case from Spanish courts). The ongoing discussion on information warfare may give rise to universal jurisdiction for Internet activity, but at the current time, no law or case exists on this point. For a discussion on information warfare, see generally Mark R. Shulman, Discrimination in the Laws of Information Warfare, 37 Colum. J. Transnat'L L. 939 (1999).

16. Restatement (Third) of Foreign Relations $\S 403$ (c)(2) (1986).

17. Cf. Wilske \& Schiller, supra note 10, at 131 (explaining the uncontroversial nature of regulating the conduct of a state's nationals anywhere in the world under the nationality principle).

18. This principle is based on the traditional "social contract" idea under which one exchanges complete freedom of action for protection and security. See infra Part II.A.

19. Starke, supra note 14, at 205.

20. See M.E. Bowman, Is International Law Ready for the Information Age?, 19 Fordham InT'L L.J. 1935, 1935 n.l (1996). 
state's territory is fundamental to the sovereignty of all nations. ${ }^{21}$ It has been said,

It is an essential attribute of the sovereignty of this realm, as of all sovereign independent States, that it should possess jurisdiction over all persons and things within its territorial limits and in all causes civil and criminal arising within these limits. ${ }^{22}$

The Westphalian-based territoriality principle has been accepted as customary international law and reaffirmed in documents such as the Montevideo Convention on the Rights and Duties of States ${ }^{23}$ and the Restatement (Third) of Foreign Relations. ${ }^{24}$

\section{The Objective Territoriality Principle}

In recent years, the principle of jurisdiction based on territoriality has been expanded beyond the traditional bounds of the subjective territoriality doctrine. Under the objective territoriality principle, the territorial basis of jurisdiction has in some cases been expanded to encompass actions that, although not occurring within a state's territory, have actual or intended effects within that state's territory. ${ }^{25}$ It is generally recognized that the action must have a sufficiently strong link to the state's territory in order to justify jurisdiction. ${ }^{26}$ In addition, the effect must be "direct, foreseeable, and substantial" within the territory. ${ }^{27}$

Even if the effect of the action is "direct, foreseeable, and substantial," the objective territoriality principle is limited to uses that do not violate the notion of

21. See Starke, supra note 14, 202-34.

22. Id. at 202 (quoting Compania Naviera Vascongado v. Cristina SS, [1938] AC 485, 496-97 (U.K.)).

23. Convention on the Rights and Duties of States, Dec. 26, 1933, T.S. No. 881,165 L.N.T.S. 19 ("[T]he jurisdiction of States within the limits of national territory applies to all the inhabitants.").

24. Restatement (Third) of Foreign Relations $\$$ 402(1)(a) (" $[\mathrm{A}]$ state has jurisdiction to prescribe law with respect to conduct that wholly or in substantial part, takes place within its territory.").

25. See United States v. Aluminum Co. of Am., 148 F.2d 416, 444 (1945); cf. United States v. Thomas, 113 F.3d 1247 (10th Cir. 1997).

26. L. Oppenheim, International Law: A Treatise 475-76 (H. Lauterpacht ed., 1955).

27. Case 89/85, Osakeyhtiö v. Commission, 1988 E.C.R. 5193, 5212 [hereinafter Re Wood Pulp Cartel]. 
sovereignty protected by international law. ${ }^{28}$ In general, a state is subject to limitations on its authority to exercise jurisdiction in cases that involve foreign interests or activities. ${ }^{29}$ "The scope of a state's sovereignty is, therefore limited and defined by the reaches of another state's sovereignty. ${ }^{30}$ It has been suggested that every state has an obligation to exercise moderation and restraint in cases regarding a foreign element in order to avoid undue encroachment on jurisdiction of other states. ${ }^{31}$ Jurisdiction under the objective territoriality principle may only be found when the claiming state does not act "in a manner which is contrary to the laws or national interests" of other states. ${ }^{32}$

As some commentators have noted, the "effects" doctrine as applied by the United States has been rejected by United Kingdom, Australia, and other countries. These countries often adopt local legislation to counter the assertion of prescriptive jurisdiction on this basis. Nonetheless, some of these countries have implicitly accepted the doctrine in such cases as Wood Pulp. In Wood Pulp, the European Commission successfully filed anti-competition suits against several U.S., Canadian, and European wood product producers that had formed a cartel outside the European Union, but whose strategies were implemented there. ${ }^{33}$

\section{A Possible Alternative: The Internet as Its Own Territory}

One important alternative to current prescriptive jurisdictional schemes is to consider the Internet as a territory unto itself. This approach attempts to obviate the problem of states infringing on the sovereignty of each other by divorcing the Internet from national laws, and instead applying a separate body of law (or no law) particularly appropriate to the Internet. David R. Johnson and David G. Post, noted proponents of the Internet as a unique territory, once stated,

Many of the jurisdictional and substantive quandaries raised by border-crossing electronic communications could be resolved by

28. Wilske \& Schiller, supra note 10 , at 146.

29. Philip C. Jessup, A Modern Law of Nations 97-99 (1950).

30. Joshua S. Bauchner, State Sovereignty and the Globalizing Effects of the Internet: A Case Study of the Privacy Debate, 26 Brook. J. INT'L L. 689, 692-93 (2000).

31. See Barcelona Traction, Light and Power Co. (Belgium v. Spain), 1970 I.C.J. 3, 105.

32. Re Wood Pulp Cartel, supra note 27, at 5213.

33. Id. 
one simple principle: conceiving of cyberspace as a distinct "place" for purpose[s] of legal analysis and recognizing a legally significant border between cyberspace [and] the "real world." ... Crossing into cyberspace is a meaningful act that would make application of a distinct law of cyberspace fair to those who pass over the electronic boundary. ${ }^{34}$

Internet theorists such as Johnson and Post (and perhaps the majority of Internet users), saw the Internet in its early "romantic era" as a world unto itself. 35 The "romantic era" embraced the vision of the Internet as a realm where humans live, not in physical form, but rather in virtual form. Further, in cyberspace, people would have experiences just as they would in any physical territory. ${ }^{36}$ The far-reaching nature of the Internet enables people to discover new things, meet new people, form relationships, engage in activities and discussion, and, although it is a stretch of imagination, engage in physical activities as a virtual person through role-playing or other video games. These people "meet, talk, and live in cyberspace in ways not possible in real space." 37

The primary difference between this virtual territory and any other territory is the intangible nature of the Internet. ${ }^{38}$ It does not exist in any one territory, nation, or state. Some would argue that it exists in every state, advancing the argument that, by existing in all states, the Internet maintains such a large territory that a "neoterritory" is formed, whose governance requires a unique set of rules. In essence, cyberspace should have its own "cyberlaw." 39 As Yaman Akdeniz stated, "The Internet is a complex, anarchic, and multi-national

34. David R. Johnson \& David G. Post, The Rise of Law on the Global Network, in Borders iN Cyberspace 3, 12-14 (Brian Kahin \& Charles Nesson eds., 1997).

35. Peter P. Swire, Of Elephants, Mice and Privacy: International Choice of Law and the Internet, 32 INT'L LAW. 991 (1998).

36. Lessig, supra note 9, at 1403. See generally Howard Rheingold, The Virtual Community: Homesteading on the Electronic Frontier (200o), available at http:/www.rheingold.com/vd book/ intro.html (last visited Apr. 9, 2003).

37. Lawrence Lessig, The Path of Cyberlaw, 104 YaLe L.J. 1743, 1746 (1995).

38. See Johnson \& Post, supra note 9, at 1387.

39. Lessig agrees that a separate law might solve some of the jurisdictional problems, but is skeptical of Johnson and Post's romantic notions of a picturesque cyberspace. Furthermore, he believes that software code (e.g., passwords and encryption to prevent trespass or copyright infringement) would be a more efficient way of regulating the Internet than a form of "cyberlaw." See Lessig, supra note 9, at 1407. 
environment where old concepts of regulation, reliant as they are upon tangibility in time and space, may not be easily applicable or enforceable." ${ }^{40}$

While thinking of the Internet as a unique and independent territory deserving of its own laws and free from the laws of nations would solve many jurisdictional problems, this idea suffers two flaws. First, the Internet is not in fact independent. The intangible Internet requires the tangible. The Internet cannot exist without the human element. Somewhere someone is physically writing the code necessary for the Internet to operate. The Internet is not in fact some ethereal body beyond the physical. As it is part of the physical realm, it must have a physical location, however difficult this may be to place. Thus, the idea of the Internet as a unique and independent territory on some separate territorial plane is false.

Second, nations have already passed laws regulating the Internet, ${ }^{41}$ demonstrating their rejection of the notion that the Internet and cyberspace are beyond the grasp of governmental powers. The United States has enacted the Digital Millenium Copyright Act, and attempted to adopt two Children's Decency Acts. ${ }^{42}$ Germany has enacted the German Information and Communications Services Act. ${ }^{43}$ France has attempted to apply general censorship laws to the Internet as well. The actions of these influential nations will likely attract the notice of other nations that will also create Internet-related legislation.

In the end, the analysis of the Internet as its own territory fails to solve the regulatory problem. The Internet is not a separate and individual territory. In recognition of this, states and courts have already sought to analyze Internet regulation using traditional theories of prescriptive jurisdiction.

40. Yaman Akdeniz, Governance of Pornogaphy and Child Pornography on the Global Internet: $A$ Muli-Layered Approach, in Law and the Internet: Regulating Cyberspace 223, 225 (Lilian Edwards \& Charlotte Waelde eds., 1997).

41. Another related problem especially prevalent in the idea of cyberlaw, is enforcement. How exactly does one enforce cyberlaw against an actor in cyberspace? Is there a "cyberprison" for consistent violators? Is this simply another argument that the Internet requires a connection with the physical world?

42. See Digital Millennium Copyright Act, Pub. L. No. 105-304, § 103, 1201-03, 112 Stat. 2860, 2862-76 (1998).

43. See Entwurf eines Gesetz zur Regelung der Rahmenbedingungen fur Informations und Kommunikationsdienste [Federal Act Establishing the General Conditions for Information and Communication Services] (luKDG) (1996) (Ger.), available at http://www.iid.de/rahmen/ iukdgebt.html [hereinafter Information and Communication Services Act]. 


\section{B. Problems with assertion of Prescriptive Jurisdiction over Internet Activity}

Two primary problems arise in the exercise of prescriptive jurisdiction over the Internet. First, what location is relevant under the subjective territoriality principle? Second, how does the element of intent for jurisdiction under the objective territoriality principle apply to passive websites? This section will first present these two issues generally and then use several cases to illustrate the specific harms that can result.

\section{The Locus Problem: Determining Location for Subjective Territoriality Jurisdiction}

As discussed earlier, states have always relied on the ability to exercise jurisdiction over property, persons, acts or occurrences within their sovereign borders. ${ }^{44}$ The fundamental complexity of applying the subjective territory principle to the Internet can be summarized in one seemingly simple question: in which territory is the Internet action in question located? Jane Ginsburg suggests that proliferation of information on the Internet nearly equates to a "simultaneous publication ... in every country of the world in which there is Internet access. ${ }^{45}$ As she points out, then, there are many answers to this question. ${ }^{46}$

One approach to the problem would be to consider the location of the Internet viewer as the location for purposes of subjective territoriality. ${ }^{47}$ For a nation concerned with what is being shown or purchased through the Internet, this seems to be the logical solution. The action of viewing or purchasing occurs within its territory and therefore the nation must have a right to regulate. While initially this solution appears to be consistent with the notion of sovereignty, in fact, it is not. This approach to jurisdiction would fall within the "simultaneous publication" dilemma. For example, one nation's censorship of materials on the Internet might clash with the legal viewing and dissemination of the same materials in another country. Therefore, basing jurisdiction on the location of the Internet viewer is an incomplete approach.

\footnotetext{
44. StARKe, supra note 14 , at 202-35.

45. Jane C. Ginsburg, The Private International Law of Copyright in an Era of Technological Change, 273 Recueil. Des Cours 239, 255 (1998).

46. See generally id.

47. $I d$. at 285 . "[The] work is not yet available to the public until it arrives at its palace of residence on the website that members of the public will access." Id. at 269.
} 
A second approach would be to consider the location of the author, creator, or greatest number of creators of the website as the proper location to apply subjective territoriality. ${ }^{48}$ However, this approach falls within the fails to answer completely the original question of location, because, like the first approach, it falls within the "simultaneous publication" dilemma. While an author may be located in a single nation, the website is made available everywhere. The website's content may be legal where it was written or entered into the Internet but illegal in one or more of the nations where it is viewed. The second approach is thus incomplete in a way similar to the first approach.

A third approach would be to apply the subjective territoriality principle based only on where the server is located, as creating a website or posting messages on the Internet requires storing-or at a minimum, transferring-the information through a central server. ${ }^{49}$ However, Jane Ginsburg posits that this theory would not solve many of the territorial complexities with jurisdiction..$^{50}$ The notion that the location of the server can serve as location of jurisdiction may be easily circumvented. Two theoretical situations serve as examples. In today's world of increasingly mobile technology, a server might be located on a ship or some other mobile unit. ${ }^{51}$ Alternatively, the location of the server may be circumvented by using phone lines to send information through several countries and several sub-servers, creating the additional problem of determining the primary server. Thus, the location of the server proves to be of little use in developing the subjective territoriality doctrine. ${ }^{52}$

Another approach is to consider the location where the website was first localized. A website address begins as an Internet protocol (IP) address, analogous to a street address for a house or business. An IP address can then be translated by one of several private registrars into an easy-to-use domain name, which is a

48. Id. at 270 .

49. Id. at $269-70$.

50. Id.

51. The mobile server is well within the realm of reality and has even made headlines in the television series ALIAS. See ALIAS: "Phase One", Season 2-Episode 13 (ABC Television broadcast, Jan. 26, 2003), synopsis available at http:/www.abc.abcnews.go.com/primetime/alias/ missions/episode213a.html.

52. Moreover, the person downloading the website may have no knowledge of the location of the website. This brings to the forefront the question whether intent is needed for application of jurisdiction, which will be discussed in the section to follow. See infra Part I.B.2; see also, e.g., Ginsburg, supra note 45 , at 270 . 
string of letters in the form of a keyword or mnemonic device ${ }^{53}$ (e.g., www.boxes.com). Many domain names include a geographic suffix, called a country code top level domain (e.g., ".uk" for the United Kingdom or ".jp" for Japan). ${ }^{54}$ Policies and regulations regarding these suffixes vary, but generally these suffixes are reserved for citizens of the countries they indicate. ${ }^{55}$ While IP addresses or domain names do not solve the problem of territorial location completely, they may potentially provide proof of location. Therefore, nations might apply the subjective territorial doctrine based on the domain name.

\section{Passive Web Sites vs. Interactive Web Sites: The Question of Intent in} Objective Territoriality

One essential problem with the objective territoriality doctrine as applied to the Internet is the question of intent. In short, this question can be framed as the "intended or stumbled upon" quandary. For example, if a person in country A posts pictures of her collection of purple tractors on her website, can country B, which outlaws the display of purple tractors, assert jurisdiction over the person based on the claim that there was an intended effect of encouraging the viewing of purple tractors? In other words, is there a difference between passive and active use of the Internet? In this case, country B applies jurisdiction based on the alleged intent to cause harm, but the individual actor merely posted the pictures on her website, which made them available to people whose nations' laws prohibit them from viewing the pictures. A vital question, then, is whose intent controls. Does the publisher's intent to make the pictures available to everyone everywhere constitute intent to cause an effect that would allow application of jurisdiction everywhere? Or does the viewer's intent to open the webpage constitute the intent to cause an effect necessary under objective territoriality?

53. InterNIC FAQs on the Domain Names, Registrars, and Registration, at http://www.internic.net/ faqs/ domain-names.html (last visited Apr. 9, 2003). These registrars register domain names in exchange for the registrant's name, contact information, and a fee. Top-level domain registrars (those who grant .com, biz, .net, .ogr, .name, .info domain names) are collectively governed by the Internet Corporation for Assigned Names and Numbers (ICANN). ICANN is a non-profit corporation that "is assuming responsibility from the U.S. Government for coordinating certain Internet technical functions, including the management of [the] Internet domain name system." Id.

54. Id.

55. Id. 
Various U.S. courts have condoned the rationale of California Software, Inc. v. Reliability Research, Inc. ${ }^{56}$ which held that a posting on the Internet purposely intended to cause harm may be enough to justify jurisdiction when there exists a reasonably strong interest in protecting the rights of a state's citizens. ${ }^{57}$ Some commentators have recommended further that the intent requirement be extended to cover passive postings on a website that cause harm as well. ${ }^{58}$

\section{Selected Cases}

The cases below illustrate the complexity of tailoring existing jurisdictional rules to Internet regulation; further, they reveal the impact that such regulation may have on individual liberty.

\section{a. CompuServe Cases}

In 1997, Germany passed the German Information and Communications Services Act. ${ }^{59}$ Among other provisions intended to restrict content of the Internet, the Act established a type of conduit liability for internet service providers (ISPs). Under the Act, ISPs had a duty to block and make unavailable materials found to be illegal under the Act. ${ }^{60}$ The Act provided that the ISPs only had such a duty when knowledge of the illegal material existed. ${ }^{61}$ However, failure to remove or block the material after it was discovered would result in criminal prosecution. $^{62}$ In addition, the Act called for independent monitoring of materials that might be deemed harmful to minors. ${ }^{63}$

56. 631 F. Supp. 1356 (C.D. Cal. 1986).

57. See, e.g., Sinatra v. National Enquirer, Inc., 854 F.2d 1191 (9th Cir. Cal. 1988); Maritz, Inc. v. Cybergold, Inc., 947 F. Supp. 1328 (E.D. Mo. 1996); Claude P. Bamberger Int'l v. Rohm \& Haas Co., 1996 U.S. Dist. LEXIS 22110 (D.N.J. 1996); Hearst Corp. v. Goldberger, 1997 U.S. Dist. LEXIS 2065 (S.D.N.Y. 1997).

58. W.S. Gale, The Impact of Information Technology upon Civil Practice and Procedure, in Law \& the Internet: Regulating Cyberspace 245, 248-49 (Lilian Edwards \& Charlotte Waelde eds., 1997).

59. See Information and Communication Services Act, supra note 43.

60. Amber Jene Sayle, Net Nation and the Digital Revolution: Regulation of Offensive Material for a New Community, 18 Wis. INT'L L.J. 257, 268-69 (2000).

61. Id.

62. Id.

63. Id. 
On December 8, 1995, German authorities delivered to CompuServe, Inc., a U.S.-based entity with an office in Germany, a list of 280 newsgroups that the German authorities believed violated German anti-pornography laws and contained material "harmful to minors." ${ }^{64}$ CompuServe was located within the United States and provided access through its servers located there. CompuServe argued that the software required to filter the prohibited materials was unavailable without subsequently barring U.S. citizens from the same material. ${ }^{65}$ The matter was ultimately resolved outside of court, and to avoid criminal prosecution, CompuServe agreed to the demands of German authorities. The result of CompuServe's concession was globally blocking the prohibited newsgroups from its service, ${ }^{66}$ thereby barring 4.3 million subscribers worldwide from access to over 200 sexually explicit discussion groups that would potentially violate German laws. ${ }^{67}$

\section{b. The Yahoo! Cases}

These cases stem from the sale of Nazi paraphernalia on Yahoo!'s online auction site. La Ligue Contre Le Racisme et L'Antisemitisme (LICRA) and L'Union des Etudiants Juifs de France (L'Union), two non-profit organizations of French citizens, sought to prohibit Yahoo!, Inc., a business incorporated in the United States and maintaining it's primary place of business in the United States, from allowing Nazi paraphernalia to be sold on Yahoo!'s auction sites. LICRA and L'Union claimed that availability of the paraphernalia violated Article R645-1 of the French Criminal Code. ${ }^{68}$ Article R645-1 prohibits the sale

64. Id. at 271 .

65. John Markoff, German Pornography Law Determines What America Sees, N.Y. Times, Dec. 31, 1995, at H2.

66. John T. Delacourt, Recent Development: The International Impact of Internet Regulation, 38 Harv. Int'L L.J. 207, 212 (1997). Despite CompuServe's agreement to block prohibited newsgroups, the German court still convicted Felix Somm, the manager of CompuServe's German subsidiary, for violating the statute and thereby punished the manager of a subsidiary for a parent company's actions. Somm's conviction, however, was overturned in 1999. See Sayle, supra note 60, at 271-72. CompuServe's agreement to block was opposed by groups throughout the world, such as many Canadians who canceled their service in protest. EFC's Registry of Canadians Opposed to CompuServe Censorship, at http://www.efc.ca/pages/cis/ registry.html (last visited Apr. 9, 2003) [hereinafter EFC's Registry of Canadians].

67. See Sayle, supra note 60 , at 271.

68. C. PÉn. art. 645-1. 
of any Nazi propaganda or artifact. ${ }^{69}$ LICRA and L'Union brought their claim before the Tribunal de Grande Instance de Paris ("the Paris Court"); subsequently, Yahoo! Sought in the U.S. District Court for the Northern District of California a declaration that any resulting judgment of the French court would not be enforced in the United States. ${ }^{70}$

In the case before the Paris Court, LICRA and L'Union successfully argued (1) that France had jurisdiction over the Yahoo! actions on the Internet, and (2) that by making Nazi paraphernalia available on the Internet, and directing the auction to French citizens through the use of a French subsidiary, Yahoo! violated the ban on the sale of such material. ${ }^{71}$ Yahoo! countered that it was unable accurately to ascertain the geographic location of Yahoo! Users, and therefore, that France lacked jurisdiction. The Paris Court held that France could rightfully prohibit Yahoo!'s ability to post the materials based on French law and the morals and sensibilities of "democratic states."72 As a result, the Paris Court ordered Yahoo! to prevent French citizens from accessing illegal material, including web pages on Yahoo.com (an American website) that contained "text, extracts or quotations from Mein Kampf and Protocol of the Elders of Zion."73 In addition, the Paris Court ordered Yahoo! to post a warning on Yahoo.fr to French citizens stating that any search for illegal Nazi paraphernalia might subject the citizen to criminal prosecution. ${ }^{74}$ Finally, the Court ordered Yahoo! to "remove from all browser directories accessible in the French Republic index headings entitled 'negationists' and from all hypertext links the equation of 'negationists' under the heading Holocaust." 75 Moreover, it indicated that failure by Yahoo! to comply with the order of the Paris Court would result in substantial monetary penalties being levied against Yahoo!. ${ }^{76}$

69. Id.

70. Yaman Akdeniz, Case Analysis of League Against Racism and Antisemitism (LICRA), French Union of Jewish Students v. Yahoo! Inc. (U.S.A.), Yahoo France, Tribunal de Grande Instance de Paris, Interim Court Order, 20 November, 2000, 1 Elec. Bus. L. Rep. 110 (2001), at http://www.cyberrights.org/documents/yahoo_ya.pdf.

71. Id.

72. Id.

73. Yahoo! Inc. v. La Ligue Contre Le Racisme et L'Antisemitisme, 169 F. Supp. 2d 1181, 1184 (N.D. Cal. 2001).

74. Id. at 1184 .

75. Id. at 1184-85.

76. Id. at 1185 . 
In Yahoo!, Inc. v. La Ligue Contre Le Racisme et L'Antisemitisme," the District Court, however, declared that the French order was unenforceable in the United States. The Court held that while France has the sovereign right to regulate speech within its borders, a U.S. court may not enforce a foreign order that chills protected free speech. The Court recognized the conflicts inherent in posting speech on the Internet because such a posting "allows one to speak in more than one place at the same time," but stated that the French regulations "clearly would be inconsistent with the First Amendment if mandated by a court in the United States. ${ }^{18}$ Moreover, the Court stated that the interest in protecting free speech outweighs the traditional respect for comity. ${ }^{79}$

\section{c. The Google Case}

CompuServe, Inc. and Yahoo! are not the only parties to experience the reach of foreign laws over their actions on the Internet. Recently, Google, Inc. found that the government of the Republic of China blocked Chinese citizens' access to Google.com and, further, redirected the citizens to Chinese government-controlled web sites. ${ }^{80}$ Google.com provides access to the largest search engine on the World Wide Web: an "index comprising more than 3 billion URLs." While no criminal charges were filed or any legal action taken by China against the company, Google, Inc. was forced to spend substantial time negotiating with the Chinese government in order to be freed of government censorship. ${ }^{82}$

\section{d. Le Grand Secret}

In another case, the owner of an Internet café in France made available via website a copy of Le Grant Secret, an unauthorized biography documenting the life of French President Francois Mitterrand ${ }^{83}$ Due to pressure from Mitterrand's

77. Id.

78. Id. at 1192 .

79. Id. at 1192-93.

80. Jason Krause, Casting a Wide 'Net: Search Engines Yahoo and Google Tussle with Foreign Courts Over Content, 88 A.B.A J. 20 (2002).

81. Google, Inc. Fact Sheet, at http://www.google.com/press/facts.html.

82. Krause, supra note 80.

83. Ginsburg, supra note 45, at 253. 
family, the French court ordered that all the copies of this book be removed from shelves throughout the country. ${ }^{84}$ The owner of the Internet café was able to copy the book and place it on the Internet before all books were forced to be returned. ${ }^{85}$ When threatened with legal action by the Mitterrand family, the owner responded that he would delete the files from his server and transfer them to a server in the United States. ${ }^{86}$ Apparently, the owner did eventually send the files to the United States and several websites carry the book in digital form. However, the website that tends to be listed first by search engines has been replaced with a statement that the website has been closed due to potential legal action. ${ }^{87}$

\section{Protecting Liberty on the Internet: The Need to Define Cyberliberty and Its Limitations}

For nearly a decade, legal scholarship has focused on rationalizing and justifying jurisdictional schemes to control the Internet. ${ }^{88}$ While attempting to control the spread of unpopular political expression, pornography, e-commerce ${ }^{89}$ and, most recently, terrorism on the World Wide Web, states have failed to recognize one of the important philosophical cornerstones of this new postWestphalian dimension. ${ }^{90}$ In the hurried actions of states to gain control of a space without a defined territory, they have attempted the impossible: to control

\section{Id.}

85. Id.

86. Id.

87. "This web page has been removed due to threats of legal action by persons claiming to represent the authors of the book which was censored in France. While I do not believe their protestations of only being concerned about intellectual property rights, I do not have either the time or the re \$ource $\$$ to fight off a legal action." Le Grand Secret, at http://www.daft.com/ rab/4iberty/lesecret (last visited Apr. 9, 2003).

88. See, e.g., Bowman, supra note 20, at 1935; Michael L. Siegel, Hate Speech, Civil Rights, and the Internet: The Jurisdictional and Human Rights Nightmare, 9 A L.в. L.J. ScI. \& Tech. 375 (1999); Eric J. Bakewell et al., Computer Crimes, 38 Am. Crim. L. Rev. 481 (2001). For a discussion of international jurisdictional problems more generally, see, e.g., Jonathan I. Charney, Universal International Law, 87 Am. J. Int'L L. 529 (1993); Christopher L. Blakesley \& Otto Lagodny, Finding Harmony Amidst Disagreement Over Extradition, Jurisdiction, the Role of Human Rights, and Issues of Extraterritoriality under International Criminal Law, 24 VAND. J. TRANSNAT'L L. I (199I).

89. See generally Chelsea P. Ferrette, E-commerce and International Political Economics: The Legal and Political Ramifications of the Internet on World Economies, 7 ILSA J. INT'L \& CoMp. L. 15 (2000).

90. When referring to the physical boundaries of the Internet, I am referring to the servers, computer hardware, software, and such other materials as the fiber optic cables. 
the Internet through the application of domestic laws without regard to the global nature of the Internet. As Professor Lessig poignantly states, "We are at a critical time in the history of cyberspace. The space is changing before we have learned what was special about the place." 91

At this critical time, as we are confronted with the unique challenges of regulating activity on the Internet, it is important that we reexamine the philosophical foundations of liberty, in order to avoid creating legal regimes that unduly impair Internet activity. The massive body of scholarship covering jurisdiction over the Internet has neglected to consider the basic philosophical underpinning of this global force. Some commentators' cursory remarks to the idea of "netizens" hint at a deeper matter, ${ }^{92}$ but little is mentioned of the unbridled freedom of the early years of the Internet. While some remember the early days of the Internet as anarchic times when the evil of pornography was freely dispersed, ${ }^{93}$ others recognize something more profound. Because activity on the Internet raises unique issues about the value of free speech, privacy, and property, it invokes discussions of liberty begun long before the Internet or computers were ever created.

Contemporary philosophers have not discussed this notion of liberty in the context of Internet activity. Several commentators and groups on the Internet have discussed the term "cyberliberty" but never defined it. In order properly to define "cyberliberty," the basic philosophic underpinning of liberty must be examined in light of contemporary problems. Once we have done this, we can create an informed definition of "cyberliberty" that will guide regulation of activity on the Internet in a way that properly balances individual rights against the regulatory power of nations.

\section{A. Philosophical Foundations of Liberty}

For generations, philosophers have debated the definition, merits, and boundaries of liberty. The thoughts of three notable philosophers stand out: Thomas Hobbes, John Locke, and John Stewart Mill.

91. Lessig, Cyberspace and Privacy: A New Legal Paradigm? Forward, 52 Stan. L. Rev. 987, 989 (2000).

92. See, e.g., Rheingold, supra note 36.

93. See, e.g., Protect Your Family with Filtered Internet Access!, World Christian Online, Inc., at http://www.worldchristian.net (Apr. 9, 2003). 
Hobbes, Locke, and Mill all agree on the fundamental principle that liberty is inherent in a state of nature. Beyond its mere existence, however, the three define liberty differently. In Leviathan, Hobbes defined liberty as "the absence of external impediments, which impediments may oft take away part of a man's power to do what he would, but cannot hinder him from using the power left him, according as his judgment and reason shall dictate to him."94 To Hobbes, liberty is not complete freedom, but rather the ability to do that which an individual has the "will, desire, or inclination to do." 95 Similarly, Lockean theory holds liberty to be the natural right to accommodate one's individual tastes to the extent that liberty of others is not impeded. ${ }^{96}$

While similar to Hobbes and Locke in some ways, Mill describes liberty as the absolute right of an individual to be sovereign over her own mind and body. Further, Mill provides a three-pronged definition of liberty. First, liberty is the freedom of thought, conscience, and the ability to express opinions on all subjects. ${ }^{97}$ Second, liberty presents the ability to formulate and follow individual tastes and preferences even to the extent to which the individual may suffer unfavorable consequences. ${ }^{98}$ Third, liberty is the freedom to unite to protect these opinions, tastes, or for general protection, even at the sake of liberty itself. ${ }^{99}$

While all three authors define liberty as a method for fulfilling one's preferences, Hobbes and Locke differ slightly with Mill as to the reason liberty is important. Hobbes argues that in nature, liberty lies in the war of all against all. "For as amongst master-less men, there is perpetual war of every man against his neighbor." ${ }^{100}$ An individual has complete freedom and can do that which is most conducive to his desires. ${ }^{101}$ But even this is not complete liberty. An individual in a war of all against all can only do what can be successfully completed without losing the battle to another. Individuals exchange natural liberty for civil laws and the rule of a sovereign, because security in property and protection can be

94. Thomas Hobbes, Leviathan 79 (Edwin Curley ed., Hackett Publ'g Co. 1994) (1668).

95. Id. at 136.

96. John Locke, Of Civil Government, in Classics of Western Thought: The Modern World 69 (Edgar E. Knoebel ed., Harcourt Brace Jovanovich Coll. Publishers 4th ed. 1988) (1690).

97. John Stewart Mill, On Liberty 11 (Elizabeth Rapaport ed., Hackett Publ'g Co. 1978) (1859).

98. Id. at $55-57$.

99. Id. at 12.

100. НоввеS, supra note 94 , at 140.

101. Id. 
found only within these two constraints. ${ }^{102}$ Within the confines established by government, individuals find true liberty.

Locke agrees with Hobbes that societies are formed out of a desire for protection. Locke states that "there is only political society where every one of the members has given up his natural power, surrendered it into the hands of the community." 103 A political society will provide protection against the war of all against all. Therefore, some measure of liberty must be forgone for the sake of peace and comfort. This in turn protects the liberty to live in this peace and comfort.

The importance of liberty to Mill has a more humanistic characteristic than to Hobbes and Locke. Following his three-pronged approach, Mill first holds that to prohibit freedom of thought, conscience, and expression in their entirety causes both harm to the essence of the individual and humanity as a whole because quieted ideas may have value and solutions for all. ${ }^{104}$ Second, the ability to formulate and follow individual tastes and preferences is necessary for the human to grow and exist, because growth and existence can only occur through making choices. ${ }^{105}$ Finally, while the individual may unite with others as a form of protection, the individual maintains a sense of individuality by not being accountable for actions that concern no one but herself. ${ }^{106}$ Only when the individual's exercise of liberty causes harm to others may it be limited. This is true for all forms of government. ${ }^{107}$

Despite their differences in definition and emphasis, Hobbes, Locke, and Mill all place similar boundaries on liberty. While all agree that liberty extends only so far as the sovereign and society permit, they also assert that collective control of the individual may only be exercised in furtherance of self-preservation. "That the only purpose for which power can be rightfully exercised over any member of a civilized community, against his will, is to prevent harm to others." 108 The primary problem with liberty lies in where to find a "fitting adjustment between individual independence and social control," that is, avoiding the tyranny of the majority. ${ }^{109}$

102. Id. at 138.

103. Locke, supra note 96 , at 72.

104. MiLL, supra note 97, at 50.

105. Id. at 55-57.

106. Id. at 93 .

107. Id. at 109-11.

108. Id. at 9.

109. Id. at 5. 
B. Contemporary Theories of Cyberliberty, and Implications for Expression, Privacy, and Intellectual Property

Fearful of the increasing attempts by countries to exercise jurisdiction over the Internet, Grateful Dead writer John Perry Barlow posted on the Internet "A Declaration of the Independence of Cyberspace." It stated,

Governments of the Industrial World, you weary giants of flesh and steel, I come from Cyberspace, the new home of the Mind. On behalf of the future, I ask you of the past to leave us alone. You are not welcome among us. You have no sovereignty where we gather. ${ }^{110}$

A search of the Library of Congress catalog will reveal no titles or books listed under the term "cyberliberty." "Similarly, a search of the Lexis system locates only seven entries, only one of which explicitly uses the word cyberliberty. ${ }^{12}$ In that article, Steven R. Salbu defines cyberliberty as a means to aid democracy by enabling free speech. ${ }^{113}$ Although various sources on the Internet use the term "cyberliberty" or "cyberliberties" in different ways ${ }^{114}$, cyberliberty is

110. John Perry Barlow, A Declaration of the Independence of Cyberspace, at http://www.eff.org/ -barlow/ declaration-final.html (Feb. 8, 1996).

111. The author conducted this search on line at http://cweb.loc.gov, on January 19, 2002, using the term "cyberliberty."

112. See Steven R. Salbu, Who Should Govern the Internet?: Monitoring and Supporting a New Frontier, 11 HaRv. J.L. \& TECH. 429 (1998).

113.

"Cyberliberty" is another benefit of the Internet. It embodies democratic ideals through the Internet's facilitation of openness and speech as values embraced in the First Amendment. For example, making governmental publications widely available for downloading can strengthen our democratic system by improving access to original documents, thereby offering an alternative to filtered information offered by the press. Likewise, the Internet can enhance democracy by enabling "cheap speech," liberating the "marketplace of ideas" from the institutional dominance of publishers, distributors, broadcast media, and other traditional gate-keepers of speech.

Id. at $436-37$.

114. Compare Pete Guither, Give Me Cyberliberty, at http://www.thelivingcanvas.com/guither/ cyber.html (last visited Apr. 10, 2003), with Timothy W. Luke, Dealing with Digital Divides: The Rough Realities of Materiality in Virtualization, paper presented at the annual meeting of the 
generally considered a matter of free expression. However, cyberliberty encompasses concerns about privacy and intellectual property as well.

\section{Cyberliberty and Free Expression}

Cyberliberty is generally considered, at least by those on the Internet, to be a particular application of free speech rights. Ian Clark, the creator of the revolutionary FreeNet program, which provides uncensorable dissemination of controversial information and universal personal publication through a computer-to-computer network, implicitly defines cyberliberty as the protector of the free flow of information. His definition of cyberliberty revolves around the basic precept that freedom of speech is "generally considered one of the most important rights any individual might have." 15 In Clark's view, freedom of expression is important for three reasons. First, communication defines humanity. ${ }^{116}$ The ability to communicate complex and abstract concepts separates humans from animals. Second, "knowledge is good." 17 Greater amounts of information improve an individual or group's ability to survive and be successful. Third, democratic governments require a well-informed populace. ${ }^{118} \mathrm{This}$ is a form of republican theory that holds that government should cultivate in citizens "qualities of character necessary to the common good of selfgovernment." 119 Clark concludes that government should not be able to control its population's ability to distribute information because of the importance of this ability to the overall freedom of the individual.

General consensus too appears to support a conception of cyberliberty predominantly as the right to free expression on the Internet. Many international organizations cite the Universal Declaration of Human Rights and the Interna-

American Sociological Association, Aug. 6-10, 1999, available at http://www.cddc.vt.edu/tim/ tims/tim687.htm. Unlike others on the Internet, Luke equates cyberliberty with freedom in general. Id.

115. Ian Clarke, The Philosophy Behind Freenet, Freener Project, at http:/I www.freenetproject.org/cgi-bin/twiki/view/main/philosophy (last visited Apr. 10, 2003).

116. Id.

117. Id.

118. Id.

119. Michael J. Sandel, Democracy's Discontent: America in Search of a Public PhilosoPHY 25 (1996). 
tional Covenant on Civil and Political Rights as a basis for this theory. ${ }^{120}$ In no place, however, is this contemporary understanding more apparent than in the United States. For example, civil liberties groups have successfully challenged the Communications Decency Act (CDA), which intended to limit access to pornography by minors, and have sued library officials who have restricted access to such Internet content. ${ }^{121}$ In Reno $v$. $A C L U$, the Supreme Court effectively held the CDA unconstitutional based on First and Fifth Amendment concerns. ${ }^{122}$

\section{Cyberliberty and Privacy}

Other advocates of Internet liberty, such as the Global Internet Liberty Campaign (GILC), extend cyberliberty beyond protection of free speech to protection against invasion of privacy. GILC argues that cyberliberty covers four areas beyond free speech. ${ }^{123}$ First, it advocates freedom from over-regulation of technologies related to Internet transmissions. ${ }^{124}$ Next, GILC strives to ensure that personal information generated for one purpose is not used for alternative purposes. ${ }^{125}$ Further, it argues for protecting private information and preventing restrictions on encryption. ${ }^{126}$ Finally, GILC advocates the right to anonymity online to ward off potential violations of human rights and to remove fears of retribution. ${ }^{127}$

120. International Bill of Human Rights: Universal Declaration of Human Rights, G.A. Res. 217A (III), U.N. GOAR, art. 19, U.N. Doc. A/810 19 (1948) ("Everyone has the right to freedom of opinion and expression; this right includes freedom to hold opinions without interference and to seek, receive and impart information and ideas through any media and regardless of frontiers."); International Bill of Human Rights: International Covenant on Civil and Political Rights, G.A. Res. 2200 A (XXI), U.N. GAOR, 21st Sess., Supp. No. 16, art. 19 U.N. Doc AXXI (1966) ("Everyone shall have the right to freedom of expression; this right shall include freedom to seek, receive, and impart information and ideas of all kinds, regardless of frontiers, either orally, in writing or in print, in the form of art, or through any other media of his choice.").

121. Courtney Macavinta, Civil Liberties On-Line: The Year That Was, News.com, at http:// news.com.com/2100-1023-219588.html (Dec. 30, 1998).

122. Reno v. ACLU, 521 U.S. 844 (1997).

123. Member Statement on "Impact of Self-Regulation and Filtering on Human Rights to Freedom of Expression, Global Internet Liberty Campaign, at http://www.gilc.org/speech/ratings/gilcoecd-398.html (Mar. 25, 1998).

124. Id.

125. Id.

126. Id.

127. Id. 


\section{Cyberliberty and Intellectual Property}

In general, intellectual property law recognizes property rights in the intangible products created by the human mind. Influential legal scholars of Internet and government regulation focus on the Internet as a necessary medium to encourage this type of creativity. ${ }^{128}$ While some may argue that this is nothing more than a free speech issue, the Internet as a creative medium presents a distinguishable regulatory dilemma.

Never before has there been a medium that allows us to try out different "and even heretical" ideas free of socioeconomic conditions, and receive feedback to our creativity immediately from all corners of the world. ${ }^{129}$ While there is little doubt that Gutenberg's printing press fundamentally changed education and public discourse, the Internet is unparalleled in its ability to do all of this more efficiently, more economically, free of ordinary politics, and "free to develop, to work ideas out, without apology." ${ }^{130}$ The very nature and structure of the Internet makes this medium extraordinarily capable of infusing creativity into a global society. The creativity occurring in this medium and the ability to use the Internet as a means of transferring creative works gives rise to an important regulatory interest of all governments: protecting intellectual property rights (IP rights).

While IP rights have been examined extensively in the literature, several recent events are worth mentioning. First, some deem the Internet to be the death of copyright. Ginsburg notes some of the problems with enforcing copyrights:

Should one look to the country where copies were (first) received? To the country from which the author uploaded the work? To the country in which is localized the website from which the work first becomes available to the public? What are the consequences of these different characterizations of publication and country of origin? ${ }^{131}$

While the Internet can be used to infringe or even rob copyright owners of the benefits of copyright, the Internet has also been used to prevent the grant of

128. Lawrence Lessig, The Death of Cyberspace, 57 WASH \& LEE L. REv. 337, 342 (2000).

129. Lessig, supra note 91, at 999.

130. Id.; see also Lessig, supra note 128, at 342.

131. Ginsburg, supra note 45 , at 255. 
a patent. For example, the Human Genome Project recently posted its map of the human genome on the Internet with the intention of maintaining that information as public knowledge and barring Celera Genomics, ${ }^{132}$ a private company, from obtaining patent rights on the human genome. ${ }^{133}$ This race to prohibit Celera from obtaining the patent caused the loss of a very valuable commodity in the patent, albeit in the name of science. From these examples, it is clear that prescriptive jurisdiction over the Internet-especially over intellectual property on the Internet-is indeed very valuable.

\section{Cyberliberty Defined}

Drawing on the philosophic foundations of liberty and contemporary notions of Internet freedom, we can define cyberliberty as the freedom, while on the Internet, from all external constraints on expression, privacy, and property, except constraints imposed by the state of which an individual or entity is a national.

\section{Freedom, While on the Internet, from All External Constraints on Expression, Privacy, and Property}

The substantive clause of the definition originates primarily in Hobbesian and Lockean philosophy. The Internet is very much like the original state of nature. Before mankind divided the earth into territorialized states, no government existed and it was a "war of all against all." The individual could act in accordance with individual tastes and preference, concerned with other individuals only to the extent necessary for survival. Locke differs from Hobbes in that he believes that reason exists in the state of nature and therefore that individual actions are naturally restrained. The origin-and perhaps some would argue the current state- of the Internet strongly resembles Hobbes's conceptualization of the state of nature and rejects Locke's belief in reason. When the Internet first became available, no expression, privacy, or property was barred. The Internet by its very nature was free from constraints.

\footnotetext{
132. The Maverick: Craig Venter, BBC News, May 30, 2000, at http://news.bbc.co.uk/1/hi/ in_depth/sci_tech/2000/human_genome/760685.stm.

133. National Human Genome Research Institute, The Human Genome Project, at http:// www.genome.gov/ page.cfm? pageid=10001694.
} 
Now, as nations attempt to regulate the Internet, it is important to retain much of the original integrity of the Internet and its ideals with cyberliberty. Mill's theory of the importance of liberty justifies the maintenance of cyberliberty. Cyberliberty protects free expression because prohibiting it would harm the essence of the individual and humanity as a whole. Also, the ability to formulate creative ideas and express one's preferences enables humans to grow and flourish. Finally, liberty on the Internet ensures a forum wherein disenfranchised actors can have a voice in globalization.

\section{Except Constraints Imposed by the State of Which an Individual or Entity Is a National}

Cyberliberty is not without limits. The individual must sacrifice some measure of natural liberty for the protection and security afforded by governance. ${ }^{134}$ In today's world, all territories have been divided into a system of nation-states. Sovereignty is and always has been the very backbone of this modern state system.

In his seminal work, A Modern Law of Nations, Philip C. Jessup defined classic sovereignty as the "ultimate freedom of national will unrestricted by law." 135 States are the ultimate source of rights, duties, and liberties under international law. Sovereign independence permits individual societies to affirm and develop their own values. The cost of societal regulations for communities and individuals must be determined by their own governments. Extranational regulations affect sovereignty by making it impossible for communities to establish independent identities. $^{136}$

To allow one nation or all nations to regulate foreign citizens or activities within other nations violates sovereignty, except, as stated in Part I, when there is a basis for regulation, such as an effect in the second jurisdiction. ${ }^{137}$ As one commentator stated, "The plurality of norms, ideas, customs, and politics within the

\footnotetext{
134. See Mill, supra note 97. This is an extension of Mill's attempt to balance the "tyranny of the majority" with the ability to take actions that do not impeded others liberty in some way. See also Alexis De Tocoueville, Democracy in America 504 (George Lawrence trans., J.P. Mayer ed., HarperCollins Publishers 1969) (1966).

135. Jessup, supra note 29 , at 1.

136. But see Declan McCullagh, Silencing the Net: The Threat to Freedom of Expression On-line, May 1996, at http:/www.epic.org/free_speech/intl/hrw_report_5_96.html (last visited Apr. 10, 2003).

137. See supra Part I.B.2.
} 
Internet community itself escapes regulation by a single entity or acquiescence to a single jurisdiction." 138 Therefore, constraints on cyberliberty may only be applied by states to members of their own community.

Regarding prescriptive jurisdiction, the above definition of cyberliberty is consistent with the nationality principle, but inconsistent with the objective territoriality principle. I would argue, rather, that the objective territoriality principle is inconsistent with cyberliberty. As Hobbes stated, natural liberty is the war of all against all. An individual chooses to give up some of his liberty in order to have protection from such strife. However, this liberty is only given to a specific sovereign, and the individual is only bound by a sovereign when he or she covenants with consent. Hobbes states, "Man in absolute liberty cannot be expected to recognize two opposing representatives of individual authority."139

Furthermore, man can only be a citizen under one sovereign. A competing sovereign places all men in a state of war, the very thing man gives up absolute liberty to avoid. ${ }^{140}$ Objective territoriality allows a sovereign to which an individual has not given up power to exercise laws to the detriment of the individual's liberty. This sovereign grants no protection in exchange for liberty, and the individual cannot choose to disobey its commands. The individual is bound without consent and therefore completely loses liberty. Under a proper sovereign, an individual only loses a portion of liberty, not all liberty. At the very minimum, the individual who consents still has the freedom to chose to remain under the sovereign or leave.

\section{The Definition of Cyberliberty Applied}

Unfortunately for both Yahoo! and CompuServe, the new definition of cyberliberty would not free these corporations from the jurisdiction of France or Germany. Both companies had subsidiaries located within and under the law of the host state. In both cases, these subsidiaries would have been entities falling within national regulation, although the parent companies would not.

This does not mean, however, that all individuals would suffer the fate of Yahoo! and CompuServe. The new definition of cyberliberty would free nonFrench and non-German individuals from the constraints of both French and

138. Bauchner, supra note 30 , at 718 .

139. Новвеs, supra note 94 , at 119.

140. Id. at 119-20. 
German regulations. For example, an artist located in Brazil would not have to fear liability for posting her painting of purple tractors on her website, as long as such a display is not illegal in the her home state. This does not mean that the painting could be viewed legally in France if France prohibits such artwork, merely that the artist would escape the jurisdictional reach of France and would not fear prosecution in French courts simply because the website is available in France. In short, non-French individuals would not be subject to liability for material that violates French regulations and is passively posted on websites or through networks.

The application of this definition of cyberliberty would have many benefits not found under the current use of the objective territoriality principle. First, application of this definition would increase certainty. Individuals could post information on the Internet, good or bad, to the benefit of creativity and advancement of knowledge and technology. Furthermore, individuals could carefully structure websites to avoid those countries which had policies or laws stifling the exchange of information on the Internet.

Second, the exchange of information allows for the expression and representation of cultural differences. Nations would be prohibited from stopping the exchange of information for all end users simply as a means of enforcing their own laws with respect to one small group of citizens.

Third, cyberliberty allows nations to regulate the Internet while increasing certainty in this regulation. Although this does not allow the complete regulation of the Internet, it does allow nations to govern their citizens. For instance, the Republic of China could continue censoring the Internet that flows into China. This ability to maintain some form of regulation properly balances against the inability to control the entire Internet. Citizens of other nations need only follow the laws of their own nations without fear of liability in others.

Finally, on an economic level, the certainty and freedom provided by this definition would reduce the economic costs of Internet services, thereby increasing access to the Internet. The sum of these benefits would aid the use of the Internet and promote its role as a key agent in globalization. 


\section{Conclusion}

Machiavelli believed that there "was no reliable way to hold onto a city ... short of demolishing the city itself." 141 Conquering the Internet is much like conquering Machiavelli's theoretical city. The Internet as we now know it has only existed in a workable fashion for a little over a decade. As the Internet has matured, states have attempted to regulate and conquer this territory-less space through various international jurisdictional principles. In doing so, states have threatened freedom of expression, commerce, and action. But, the Internet is an important agent of globalization and must be free to expand as a neutral zone. The need to expand the role of the Internet must be balanced with the sovereign right of nations over their citizens.

The definition of cyberliberty asserted here will not satisfy some and potentially flies in the face of the current attempts to regulate the Internet, especially under the objective territoriality principle. Fully realizing that the objective territoriality principle continues to grow in use, the definition seeks to restore the lost notion of nationality into the debate over Internet jurisdiction. As witnessed by the problems surrounding the territoriality principles and the benefits of the nationality approach, nationality must be included as an integral factor of consideration, if not a truly viable option on its own.

141. Niccolo Machiavelli, The Prince, in Selected Political Writings 17 (David Wootton ed., Hackett Publishing Company 1994) (1515). 